\title{
PRODUCTION OF BEEF MEAT WITH FUNCTIONAL FOOD ROPERTIES
}

\author{
Lj. Sretenović, V. Pantelić, M. Novaković, Ž. Novaković, D. Ostojić- \\ Andrić
}

Institute for Animal Husbandry, Autoput 16, P. Box 23, 11080 Belgrade-Zemun, Republic of Serbia Corresponding author: sretenlj@gmail.com

Invited paper

Abstract: In this study the effects of „Tradi-Lin“ as a source of omega-3 fatty acids (FA) in diets for fattening cattle were presented. „Tradi-Lin“ produced from flax seed had 58\% omega-3 and 15\% omega-6 fatty acids of total polyunsaturated fatty acids (PUFA). Trial was carried out on three groups of finishing beef cattle $\left(C, T_{1}\right.$ and $\left.\mathrm{T}_{2}\right)$ with 15 heads in each and was lasted 60 days. The diets used based on maize silage and concentrate mixture. Cattle received 0 , 300 and $700 \mathrm{~g}$ of „Tradi-Lin“ per day, respectively. At the end of trial heads were slaughtered and major parameters of the chemical composition and meat quality were determined. The results indicated that were no differences in saturated (50.85; $50.21 ; 50.34 \%)$ and unsaturated $(49.15 ; 49.79 ; 49.66 \%)$ FA between treatments in intramuscular fat of the m. longissimus dorsi but „Tradi-Lin“ influenced the changes in structure of intramuscular fat and increased PUFA from 4.91 (C) to 5.54 $\left(\mathrm{T}_{1}\right)$ and $7.31 \%\left(\mathrm{~T}_{2}\right)(\mathrm{P}<0.05)$. The increase of omega-3 FA from $0.36(\mathrm{C})$ to 0.60 $\left(\mathrm{T}_{1}\right)$ and $0.76 \%\left(\mathrm{~T}_{2}\right)$ must be pointed out, $(\mathrm{P}<0.05)$. The omega-6 FA were also increased from $4.51(\mathrm{C})$ to $4.94\left(\mathrm{~T}_{1}\right)$ and $6.22 \%\left(\mathrm{~T}_{2}\right)(\mathrm{P}>0.05)$ but omega-6: omega3 ratio was reduced from $12.25(\mathrm{C})$ to $8.22\left(\mathrm{~T}_{1}\right)(\mathrm{P}<0.05)$ and $8.62\left(\mathrm{~T}_{2}\right),(\mathrm{P}<0.01)$. Trans unsaturated $\mathrm{FA}$ which are undesirable were decreased from $3.37 \%$ (C) to $2.43 \%\left(\mathrm{~T}_{1}\right)$ and $2.36 \%\left(\mathrm{~T}_{2}\right)(\mathrm{P}<0.05)$. From nutritional aspect those results have a great importance, having in mind that omega-3 FA have a vital role in human health.

Key words: functional food, beef meat, omega-3 fatty acids

\section{Introduction}

The term "functional food" includes the food stuffs which beside their basic main nutritive value, contain the essential substances with potential positive effects on body and mental health. More precisely, this food should consist of functional food nutrients with certain specific properties, they are main part of 
every day nutrition and exclusively of natural origin, i.e. they cannot consist of tablets, capsules, solutions, powders, etc. It should contribute to improvement of body functions, increase of immunity, faster recovery from diseases, slowing of the aging process, etc. Functional food should contain ample functional food stuffs, adequate amounts of food should be consumed, food should be diverse and with uniform presence in nutrition (Sretenović et al., 2009; Sretenović et al., 2009a). This concept was introduced in Japan in the eighties of the last century.

In realized studies, source of omega-3 fatty acids the product of French company Vitalac known under the commercial name «Tradi-Lin» produced from a fully patented extrusion process, was used. What are the characteristics of TradiLin? Varieties are specially selected for their richness in ALA omega- 3 fatty acids, seeds are treated by a patented extrusion technology which liberates the oils without denaturing them so they can be digested more rapidly, inactivates the antinutritional factors (cyanogens), preserves the fatty acid profile, this process releases the omega-3 fatty acids contained in linseed in such a way that it is available to the animal at the right time and at the right dose. The omega- 3 fatty acids in raw linseed seed, cracked linseed or even linseed oil is not as available to animals, making them an inferior source. Tradi-Lin addresses the whole food chain - in an "holistic" approach rather than the quick fix, pop another pill attitude.

By feeding our animals correctly we address the fundamental problem of consuming too much omega- 6 fatty acids at the expense of too little omega- 3 fatty acids without actually changing our diet - ,we are what we eat”. If we feed our animals with linseed, the omega -3 from the linseed is passed onto ourselves in the meat, milk, eggs, butter and cheese etc. Also modern biotechnologies offer different ways for enriching of products with omega-3 fatty acids (Sretenović et al., 2007). But the really good news is that animals are able to convert some of the omega- 3 fatty acids into EPA and DHA - in fact they are significantly better at it than humans are, that's why it is better to feed the animals with linseed than to eat it directly ourselves.

Typically $60 \%$ of fat intake for an average human comes from animal products (meat, milk, eggs, etc). These animal products have changed because the feeds that the animals now eat have changed. Animals used to eat mainly forage (high omega - 3 fatty acids, lower omega- 6 fatty acids) but now typically eat less forage but consume more cereals and soya (high omega- 6 fatty acids, low omega3 fatty acids). As a result the animal products (meat, milk, eggs etc) are much higher in omega- 6 fatty acids and lower in omega -3 fatty acids, so now the human diet, because of what animals are fed, is higher in omega- 6 fatty acids and lower in omega -3 fatty acids. $40-50$ years ago traditional diets gave an omega- 6: omega3 ratio of $1: 1$, current human diets show a ratio of $20: 1$ and in animal diets up to 40:1.

It is well known that human body cannot synthesize omega fatty acids which makes it "essential fatty acids" which indicates that it is necessary to 
introduce them to organism through food. Research indicates several possible human health benefits associated with consumption of flax (Connor, 2000). It is necessary to affirm that a raised level of omega- 3 fatty acids in the tissues also correlates to a reduction in the risk of certain cancers (Legrand et al., 2001), and a reduction in the frequency of certain mental illnesses such as depression (Iribarren et al., 2004), or neuro-degenerative disorders such as Alzheimer's Disease (Laurin et al., 2003). Flax contains approximately 20 percent alpha-linolenic acid (ALA; DM basis), an essential omega-3 fatty acid that is a precursor for eicosapentaenoic acid (EPA), which in turn is a precursor for the formation of eicosanoids. Eicosanoids are hormone-like compounds that play an essential role in immune response. Additionally, some evidence suggests EPA can elongate further to docosahexanoic acid (DHA), an omega-3 fatty acid that is essential for cell membrane integrity, as well as brain and eye health (Connor, 2000). Flax also is the richest plant source of the lignan precursor secoisolariciresinol diglycoside (SDG), which the rumen microorganisms or the hind gut microorganisms in nonruminant animals convert to mammalian phytoestrogens (Thompson et al., 2004). Phytoestrogens are thought to have potential uses in hormone replacement therapies and cancer prevention (Harris and Haggerty, 1993). These observations show the central role played by polyunsaturated fatty acids in the functioning of our and animal organism. In order to overcome numerous health problems, the food stuffs which aren't traditional sources of omega-3 fatty acids such as dairy products and pastry, meat, baby foods, etc. are enriched with moderate quantities of these fatty acids and there is increased demand for such products because of their well known positive effect on human health (Sretenović et al., 2007).

\section{Materials and Methods}

The trial was carried out on experimental farm of the Institute for Animal Husbandry, to obtain meat enriched with omega -3 fatty acids. Source of omega 3 fatty acids was the product „Tradi-Lin“ and the advantage of this product in regard to all others flax qualities is that the producers in it guarantee certain content of omega -3 fatty acids, i.e. certain omega $-6 /$ omega -3 ratio in the final product. Trial was designed as a factorial, i.e. control group (C - without flax) and two trial groups $\left(T_{1}\right)$ which received 300 and $\left(T_{2}\right)$ which received $700 \mathrm{~g}$ of flax in the last two months of fattening, with objective to determine if the quantity of consumed flax influences the quantity of omega -3 fatty acids deposited in the meat. Research was done on Simmental breed cattle in the free/loose system of housing, nutrition was based on corn silage and concentrate mixture in accordance to contemporary feeding norms $(N R C, 2001)$ for this cattle breed. Free/loose housing system is in concordance to recommendations by European Union which will soon replace all other existing systems. Animals were fed twice a day, in the 
morning and evening, first with roughage and then concentrate mixtures. Concentrate mixture was produced in the feed mill of the Institute according to norms for weight categories of animals and breed. Initial body mass of young cattle in the control group was $457.2 \mathrm{~kg}$ and of trial group $452.9 \mathrm{~kg}$. Animals in control and trial groups were fed identical diet consisting of $12 \mathrm{~kg}$ of silage of whole corn plant and $7.5 \mathrm{~kg}$ of complete concentrate mixture (12\% of total proteins). The only difference was that cattle in trial groups received in addition to main diet certain amount of heat treated flax and which was strictly recorded. Composition of concentrate mixture was following (\%): corn grain - 67.8; livestock meal - 10.0; sunflower meal -16.0; lime -1.4; monocalcium phosphate-3; salt -0.8 and mineralvitamin pre-mixture - 1.0. Diet contained: $10.177 \mathrm{~kg}$ of dry matter; $80.490 \mathrm{MJ}$ NEM-a; $11.935 \mathrm{OHJ} ; 1199 \mathrm{~g}$ total proteins $(11.78 \%$ in dry matter); $1250 \mathrm{~g}$ crude fibre (12.28\% in dry matter of the diet).

Preparation „Tradi-Lin“ contained 58\% of omega-3 fatty acids and $15 \%$ of omega- 6 fatty acids in relation to content of total fatty acids, which indicates relatively favourable ratio of these two fatty acids. The chemical composition of this preparation was determined in the Laboratory of the Institute for Animal Husbandry, Belgrade-Zemun, and it was at follows: $18.61 \%$ total proteins, $9.78 \%$ crude fibre, $5.68 \%$ ash, $25.48 \%$ fat of iodine number - $172.29, \mathrm{~g} \mathrm{~J} / 100 \mathrm{~g}$ fat of acid number $-2.07,10 \mathrm{mg} \mathrm{KOH} / \mathrm{g}$ of fat and peroxide number $-2.66, \mathrm{mmol}_{2} \mathrm{O}_{2} / \mathrm{kg}$ of fat.

Content of omega -3 and omega -6 fatty acids was tested in other varieties of flax seed and results are presented in Table 1 .

Table 1. Content of omega-3 and omega-6 fatty acids in different varieties of flex seeds

\begin{tabular}{|l|c|c|}
\hline $\begin{array}{l}\text { \% omega fatty acids/total fatty } \\
\text { acids }\end{array}$ & Omega-3 fatty acids & Omega-6 fatty acids \\
\hline Flax-variety „TradiLin“ & 58 & 15 \\
\hline Flax-Lutea & 70 & 7 \\
\hline Flax-appr. all the rest & 50 & 20 \\
\hline Flax-variety Linola & 3 & 75 \\
\hline
\end{tabular}

When young cattle reached desired final body masses, they were weighed before slaughtering and slaughtered in experimental slaughterhouse of the Institute, total dissection of carcass sides was done as well as share of individual tissues determined, including chemical composition and quality of meat. The content of fatty acids (\%) was determined in the intramuscular fat of the $m$. longissimus dorsi in the back section and in intermuscular fat of the leg from all animals. Chemical composition of meat was determined by using following methods: water content by drying of samples at the temperature of $102^{\circ} \mathrm{C}$; content of mineral substances by burning at $525^{\circ} \mathrm{C}$; protein content by method according to Kjeldahl; content of intramuscular fat was determined using the method of extraction according to 
Soxlet. All stated methods of chemical analysis were done according to $A O A C$ (1990). Fatty acids were determined by method of gas chromatography (Shimadzu, GC-2014); consistency of meat according to Wolodkewitch; content of total pigments was determined according to method by Horsney; meat colour was determined on the apparatus Minolta Chroma Meter CR-400 (Minolta Co., Ltd., Osaka, Japan); cooking loss and roasting loss was expresed as difference in mass of sample before and after heat treatment; sensory properties (smell, tenderness, succulence and aroma) were determined on samples of roasted meat and were recorded from 1 to 5 . The higher score marked better or more desirable quality. Sensory panel evaluations were performed according to AMSA (1995) guidelines. The samples for sensory analysis were prepared and were served to 9 trained judges and asked them to discriminate between the different samples. A minimum of 10 correct responses was establish to find a significant $(\mathrm{P}=0.05)$ difeference between the samples.

The data from the experiment were developed statistically by using the computer program Statistica (Stat Soft Inc., Ver.6, 2003).

\section{Results and Discussion}

The content of fatty acids and their ratios in intramuscular fat of the $m$. longissimus dorsi is presented in Table 2.

Obtained results indicate that was no difference in content of saturated (SAT), $(50,85 ; 50,21 ; 50,34 \%)$ and unsaturated (UFA), $(49,15 ; 49,79 ; 49,66 \%)$ fatty acids between studied treatments $\left(\mathrm{C}, \mathrm{T}_{1}\right.$ and $\left.\mathrm{T}_{2}\right)(\mathrm{P}>0.05)$ in intramuscular fat in the $m$. longissimus dorsi of the back section. Total content of poly unsaturated fatty acids (PUFA) showed differences between treatments and recorded values were 4.95, 5.98 and $7.31 \%(\mathrm{P}<0.05)$. Addition of „Tradi-Lin“ not only affected the change in total content of PUFA between treatments, but it also contributed to significant increase of alfa linoleic acid of 0.184 (C) to 0.352 (T1) and 0.472 (T2) $(\mathrm{P}<0.05)$, as well as total omega -3 fatty acids from $0.36(\mathrm{C})$ to $0.60\left(\mathrm{~T}_{1}\right)$ and $0.76\left(\mathrm{~T}_{2}\right)(\mathrm{P}<0.05)$. No difference between treatments was recorded in the quantity of omega -6 fatty acids $(n-6)(\mathrm{P}>0.05)$. It should be emphasized that $n-6: n-3$ ratio determined in studied treatments was $12.25(\mathrm{O}) ; 8.22\left(\mathrm{~T}_{1}\right)$ and $8.62\left(\mathrm{~T}_{2}\right)$, with statistical significance of differences established between treatments $\mathrm{T}_{1}$ and $\mathrm{C}$ at the level of $\mathrm{P}<0.05$, whereas between $\mathrm{T}_{2}$ and $\mathrm{C}$ differences were highly statistically significant at the level of $\mathrm{P}<0.01$, which was very important from the nutritional aspect. Content of trans fatty acids, whose presence is undesirable from the aspect of human nutrition, was reduced significantly between control and trial groups $(\mathrm{P}<0.05)$. 
Table 2. Content of fatty acids and their mutual ratios in intramuscular fat of the $m$. longissimus dorsi in the back section, $\%$

\begin{tabular}{|c|c|c|c|c|c|c|}
\hline \multirow[b]{2}{*}{ Fatty acids } & \multicolumn{3}{|c|}{ Diet $^{1}$} & \multicolumn{3}{|c|}{$\mathrm{P}$ value ${ }^{2}$} \\
\hline & Control & $\mathrm{T}_{1}$ & $\mathrm{~T}_{2}$ & $\begin{array}{c}\text { Control } \\
\text { vs. }_{1}\end{array}$ & $\begin{array}{c}\text { Control } \\
\text { vs. } T_{2}\end{array}$ & $\begin{array}{c}\mathrm{T}_{1} \\
\text { vs. } \mathrm{T}_{2}\end{array}$ \\
\hline $14: 0$ & 2.258 & 2.241 & 2.278 & $\mathrm{NZ}$ & $\mathrm{NZ}$ & $\mathrm{NZ}$ \\
\hline $15: 0$ & 0.464 & 0.499 & 0.458 & $\mathrm{NZ}$ & $\mathrm{NZ}$ & $\mathrm{NZ}$ \\
\hline $16: 0$ & 24.356 & 23.817 & 23.992 & NZ & $\mathrm{NZ}$ & $\mathrm{NZ}$ \\
\hline $16: 1 n-7$ & 2.018 & 2.084 & 1.928 & NZ & $\mathrm{NZ}$ & $\mathrm{P}<0.05$ \\
\hline $17: 0$ & 1.068 & 1.202 & 0.960 & NZ & NZ & $\mathrm{NZ}$ \\
\hline $18: 0$ & 22.702 & 22.441 & 22.652 & $\mathrm{NZ}$ & $\mathrm{NZ}$ & $\mathrm{NZ}$ \\
\hline 18:1 trans & 3.370 & 2.431 & 2.361 & $\mathrm{P}<0.05$ & $\mathrm{P}<0.05$ & $\mathrm{NZ}$ \\
\hline $18: 1 n-9$ & 37.144 & 37.209 & 35.498 & $\mathrm{NZ}$ & NZ & $\mathrm{NZ}$ \\
\hline $18: 1 n-7$ & 1.654 & 1.705 & 1.756 & $\mathrm{NZ}$ & $\mathrm{NZ}$ & $\mathrm{NZ}$ \\
\hline $18: 2 n-6$ & 3.866 & 4.251 & 5.664 & $\mathrm{NZ}$ & $\mathrm{NZ}$ & $\mathrm{NZ}$ \\
\hline $18: 3 n-3$ & 0.184 & 0.352 & 0.472 & $\mathrm{P}<0.05$ & $\mathrm{P}<0.05$ & NZ \\
\hline $20: 1 n-9$ & 0.206 & 0.235 & 0.210 & $\mathrm{NZ}$ & $\mathrm{NZ}$ & $\mathrm{NZ}$ \\
\hline $20: 2 n-6$ & 0.014 & 0.071 & 0.080 & $\mathrm{NZ}$ & $\mathrm{NZ}$ & $\mathrm{NZ}$ \\
\hline $20: 3 n-3$ & 0.224 & 0.196 & 0.235 & $\mathrm{NZ}$ & $\mathrm{NZ}$ & $\mathrm{NZ}$ \\
\hline $20: 4 n-6$ & 0.510 & 0.476 & 0.724 & NZ & $\mathrm{NZ}$ & NZ \\
\hline $20: 5 n-3$ & 0.042 & 0.050 & 0.054 & $\mathrm{NZ}$ & $\mathrm{NZ}$ & $\mathrm{NZ}$ \\
\hline $22: 4 n-6$ & 0.124 & 0.143 & 0.124 & $\mathrm{NZ}$ & $\mathrm{NZ}$ & $\mathrm{NZ}$ \\
\hline SAT & 50.85 & 50.21 & 50.34 & NZ & NZ & NZ \\
\hline UFA $^{2}$ & 49.15 & 49.79 & 49.66 & NZ & $\mathrm{NZ}$ & $\mathrm{NZ}$ \\
\hline MUFA & 44.19 & 44.26 & 42.37 & $\mathrm{NZ}$ & $\mathrm{NZ}$ & $\mathrm{NZ}$ \\
\hline PUFA & 4.95 & 5.98 & 7.31 & $\mathrm{P}<0.05$ & $\mathrm{P}<0.05$ & $\mathrm{P}<0.05$ \\
\hline$n-3^{3}$ & 0.36 & 0.60 & 0.76 & $\mathrm{P}<0.05$ & $\mathrm{P}<0.05$ & $\mathrm{NZ}$ \\
\hline$n-6^{3}$ & 4.51 & 4.94 & 6.22 & NZ & $\mathrm{NZ}$ & $\mathrm{NZ}$ \\
\hline$n-3: n-6^{3}$ & 0.10 & 0.12 & 0.12 & NZ & NZ & $\mathrm{NZ}$ \\
\hline$n-6: n-3^{3}$ & 12.25 & 8.22 & 8.62 & $\mathrm{P}<0.01$ & $\mathrm{P}<0.01$ & NZ \\
\hline UFA:SAT $^{3}$ & 0.97 & 0.99 & 0.99 & $\mathrm{NZ}$ & $\mathrm{NZ}$ & $\mathrm{NZ}$ \\
\hline PUFA:MUFA & 0.11 & 0.12 & 0.17 & NZ & NZ & $\mathrm{NZ}$ \\
\hline MUFA:SAT ${ }^{3}$ & 0.87 & 0.88 & 0.85 & NZ & NZ & $\mathrm{NZ}$ \\
\hline PUFA:SAT ${ }^{3}$ & 0.10 & 0.11 & 0.15 & $\mathrm{NZ}$ & NZ & NZ \\
\hline
\end{tabular}

${ }^{1}$ Control =control corn-based diet; T1 $=300 \mathrm{~g}$ „TRADI-LIN“ daily; T2=700g,,TRADI-LIN “ daily; ${ }^{2} \mathrm{P}$-value for $\mathrm{F}$ test for treatment ${ }^{3} \mathrm{UFA}=$ unsaturated fatty acids, $\mathrm{n}-3=$ omega- 3 fatty acids, $\mathrm{n}-6=$ omega6 fatty acids, UFA=unsaturated fatty acids, MUFA=monounsaturated fatty acids, PUFA= polyunsaturated fatty acids, SAT $=$ saturated fatty acids; NZ-P $>0.05$

Based on previous table it can be concluded that addition of specifically heat treated flax seed influenced the change in the structure of intramuscular fat in favour of desirable n-3 fatty acids as well as significant decrease of the omega-6: omega-3 ratio which resulted in improved quality of beef, which was objective of the research.

When results obtained in this study are compared to results obtained by other researchers, it can be concluded that there was high level of concordance between them. Maddock et al., (2003) pointed out that due to an increase in 
consumer interest surrounding dietary omega-3 fatty acids, researchers have hypothesized that flax inclusion in feedlot diets will alter end-product fatty-acid profiles positively and research has proven that this occurs. Muscle from steers fed diets that included flax had higher ALA content (47 g/ $\mathrm{kg}$ lipid), compared with those steers fed either basal corn ( $34 \mathrm{~g} / \mathrm{kg}$ lipid) or barley (39 $\mathrm{g} / \mathrm{kg}$ lipid) diets. Steers fed 5 percent flax had higher muscle levels of ALA than steers fed no flax (Drouillard et al., 2002, 2004) reported increased ALA content in both muscle and fat samples collected from Holstein steers fed 5 percent flax for either 109 or 157 days, compared with control steers. Drouillard et al. (2000, 2004) also reported increases in EPA and DHA in beef from cattle offered. When using flax in beef cattle diets, Drouillard et al. (2004) offered beef steers 0, 5, 10 and 15\% flax and noted a linear decrease in DM intake as flax levels increased. Additionally, because of its relatively high protein content (22.8 percent; Lardy and Anderson, 1999), flax might be considered a source of supplemental protein; however, considerations for oil content may limit the amount of protein flax might add in a ruminant diet.). Maddock et al. (2006) fed whole or processed (rolled or ground) flax, included at 8 percent of diet DM, and reported significant increases in gain and gain efficiency and no differences in DM intake when compared with a corn-based control diet. Additionally, data from this study suggests that processing flax is necessary to optimize gain and nutrient utilization. When flax was rolled or ground, gain and gain efficiency increased, compared with feeding whole flax. Flax inclusion increased $\mathrm{ADG}(P=0.006)$ and $\mathrm{G}: \mathrm{F}(P=0.006)$, whereas processing (RLD or GRD) increased ADG $(P=0.05)$ and $\mathrm{G}: \mathrm{F}(P=0.08)$ when compared with WHL. Heifers fed flax had greater phospholipid proportions of ALA $(P<0.001)$, arachidic acid (20:0; $P=0.001)$, eicosapentaenoic acid (EPA; 20:5n-3; $P<0.001$ ), erucic acid (22:1n-9; $P=0.003)$, docosapentaenoic acid (DPAn-3; 22:5n-3; $P<$ $0.001)$, and docosahexaenoic acid (DHA; 22:6n-3; $P=0.02$ ) compared with control heifers. Processing flax increased phospholipid proportions of ALA $(P<$ $0.001)$, arachidic acid $(P=0.03)$, EPA $(P=0.007)$, DPAn-3 $(P=0.003)$, and DHA $(P=0.01)$. Heifers fed GRD had greater phospholipid ALA $(P=0.04)$ than those fed RLD. Flax addition reduced phospholipid gamma-linolenic acid (18:3n-6; $P<$ $0.001)$, dihomo-gamma-linolenic acid $(20: 3 n-6 ; P<0.001)$, arachidonic acid (20:4n-6; $P<0.001)$, and docosatrienoic acid $(22: 3 n-3 ; P<0.001)$ compared with control heifers. Flax addition did not increase $(P=0.65)$ PUFA content of phospholipids. The n-3:n-6 ratio was increased by both flax addition $(P<0.001)$ and processing $(P=0.002)$. The $n-6: n-3$ ratio was decreased by both flax addition $(P<0.001)$ and processing $(P=0.007)$. These changes in fatty acid ratios may have implications of human health with respect to interest in increasing n-3 fatty acid intake (Connor, 2000).

Composition of fatty acids in intermuscular fat in the leg is presented in Table 3. 
Table 3. Content of fatty acids and their mutual relationship in intermuscular fat of the leg, \%

\begin{tabular}{|l|c|c|c|c|c|c|}
\hline \multirow{2}{*}{ Fatty acids } & \multicolumn{3}{|c|}{ Diet $^{1}$} & \multicolumn{3}{c|}{ P value $^{2}$} \\
\cline { 2 - 7 } & Control & $\mathrm{T}_{1}$ & $\mathrm{~T}_{2}$ & $\begin{array}{c}\text { Control } \\
\text { vs. } T_{1}\end{array}$ & $\begin{array}{c}\text { Control } \\
\text { vs. }_{2}\end{array}$ & $\begin{array}{c}\mathrm{T}_{1} \\
\text { vs. }_{2}\end{array}$ \\
\hline SAT & 55.97 & 55.74 & 55.53 & $\mathrm{NZ}$ & $\mathrm{NZ}$ & $\mathrm{NZ}$ \\
\hline UFA & 43.09 & 43.83 & 44.46 & $\mathrm{NZ}$ & $\mathrm{NZ}$ & $\mathrm{NZ}$ \\
\hline MUFA & 38.88 & 39.03 & 39.43 & $\mathrm{NZ}$ & $\mathrm{NZ}$ & $\mathrm{NZ}$ \\
\hline PUFA & 4.01 & 4.50 & 5.03 & $\mathrm{P}<0.05$ & $\mathrm{P}<0.05$ & $\mathrm{NZ}$ \\
\hline $18: 3(\mathrm{n}-3)$ & 0.17 & 0.31 & 0.37 & $\mathrm{P}<0.05$ & $\mathrm{P}<0.05$ & $\mathrm{NZ}$ \\
\hline n-6 & 3.71 & 3.69 & 4.21 & $\mathrm{NZ}$ & $\mathrm{NZ}$ & $\mathrm{NZ}$ \\
\hline n-6:n-3 & 21.82 & 11.90 & 11.37 & $\mathrm{P}<0.05$ & $\mathrm{P}<0.05$ & $\mathrm{NZ}$ \\
\hline UFA:sat & 0.77 & 0.79 & 0.80 & $\mathrm{NZ}$ & $\mathrm{NZ}$ & $\mathrm{NZ}$ \\
\hline PUFA:MUFA & 0.11 & 0.12 & 0.13 & $\mathrm{NZ}$ & $\mathrm{NZ}$ & $\mathrm{NZ}$ \\
\hline MUFA:SAT & 0.69 & 0.70 & 0.71 & $\mathrm{NZ}$ & $\mathrm{NZ}$ & $\mathrm{NZ}$ \\
\hline PUFA:SAT & 0.08 & 0.08 & 0.09 & $\mathrm{NZ}$ & $\mathrm{NZ}$ & $\mathrm{NZ}$ \\
\hline
\end{tabular}

${ }^{1}$ Control =control corn-based diet; T1 $=300 \mathrm{~g}$ „TRADI-LIN“ daily; T2=700g,TRADI-LIN “ daily; ${ }^{2} \mathrm{P}$-value for $\mathrm{F}$ test for treatment ${ }^{3} \mathrm{UFA}=$ unsaturated fatty acids, $\mathrm{n}-3=$ omega- 3 fatty acids, $\mathrm{n}-6=$ omega6 fatty acids, UFA=unsaturated fatty acids, MUFA=monounsaturated fatty acids, PUFA= polyunsaturated fatty acids, SAT $=$ saturated fatty acids; NZ-P $>0.05$

Almost identical trend of distribution of certain fatty acids is observed, as well as content of fatty acids in intramuscular fat tissue, which was expected. Data presented in table show absence of differences in content of SAT, UFA, and MUFA ( $\mathrm{P}>0.05)$.

Presented results indicate that significant increase of content of PUFA occurred in intermuscular fat $(\mathrm{P}<0.05)$. Of all omega-3 fatty acids only the presence of alfa linoleic acid was determined and its content according to treatments $\mathrm{C}, \mathrm{T}_{1}$ and $\mathrm{T}_{2}$ - was $0.17 ; 0.31$ and $0.37 \%$, respectively $(\mathrm{P}<0.05)$. Content of omega- 6 fatty acids showed no differences between treatments and recorded values were $3.48 ; 3.71$ and $4.21 \%$, respectively $(\mathrm{P}>0.05)$. The omega-6: omega-3 ratio decreased significantly from 21.82 to 11.90 and $11.37(\mathrm{P}<0.05)$. Finally, identical trend of distribution of fatty acids in intramuscular and intermuscular fat was observed, which was expected.

Results of the chemical composition, technological properties, colour, marbling and sensory properties of $m$. longissimus dorsi are presented in Table 4. 
Table 4. Chemical composition and meat quality of $\mathrm{m}$. longissimus dorsi

\begin{tabular}{|l|c|c|c|c|c|c|}
\hline \multirow{2}{*}{\begin{tabular}{l} 
Chemical composition,\% \\
\cline { 2 - 7 }
\end{tabular}} & \multicolumn{3}{|c|}{ Diet $^{1}$} & \multicolumn{3}{c|}{$\mathrm{P}_{\text {value }}{ }^{2}$} \\
\hline Moisture & 74.99 & 74.71 & 75.14 & $\mathrm{NZ}$ & $\mathrm{NZ}$ & $\mathrm{NZ}$ \\
\hline Intermuscular fat & 1.56 & 1.61 & 1.69 & $\mathrm{NZ}$ & $\mathrm{NZ}$ & $\mathrm{NZ}$ \\
\hline Mineral matter & 1.13 & 1.11 & 1.12 & $\mathrm{NZ}$ & $\mathrm{NZ}$ & $\mathrm{NZ}$ \\
\hline Protein & 22.17 & 22.53 & 21.88 & $\mathrm{NZ}$ & $\mathrm{NZ}$ & $\mathrm{NZ}$ \\
\hline Technological properties,\% & & & & $\mathrm{NZ}$ & $\mathrm{NZ}$ & $\mathrm{NZ}$ \\
\hline Cooking loss & 41.83 & 41.66 & 42.42 & $\mathrm{NZ}$ & $\mathrm{NZ}$ & $\mathrm{NZ}$ \\
\hline Roasting loss & 40.35 & 40.01 & 40.77 & $\mathrm{NZ}$ & $\mathrm{NZ}$ & $\mathrm{NZ}$ \\
\hline Tenderness & 11.60 & 9.90 & 9.74 & $\mathrm{P}<0.05$ & $\mathrm{P}<0.05$ & $\mathrm{NZ}$ \\
\hline Colour & & & & & & \\
\hline Total pigments, mg/kg & 139.18 & 136.00 & 130.02 & $\mathrm{P}<0.05$ & $\mathrm{P}<0.05$ & $\mathrm{P}<0.05$ \\
\hline $\begin{array}{l}\text { Colour (Minolta), } \\
\text { lightness(Light) }\end{array}$ & 34.13 & 36.13 & 38.26 & $\mathrm{P}<0.05$ & $\mathrm{P}<0.05$ & $\mathrm{P}<0.05$ \\
\hline \multicolumn{1}{c|}{ Marbling } & 1.90 & 1.30 & 1.40 & $\mathrm{NZ}$ & $\mathrm{NZ}$ & $\mathrm{NZ}$ \\
\hline $\begin{array}{l}\text { 5. Sensory scoring } \\
\text { roasted meat }\end{array}$ & & & & & & \\
\hline Smell/Odour & & & & & & \\
\hline Tenderness & 4.20 & 4.62 & 4.40 & $\mathrm{NZ}$ & $\mathrm{NZ}$ & $\mathrm{NZ}$ \\
\hline Succulence & 3.87 & 3.63 & 4.30 & $\mathrm{NZ}$ & $\mathrm{NZ}$ & $\mathrm{NZ}$ \\
\hline Aroma & 3.93 & 3.81 & 4.10 & $\mathrm{NZ}$ & $\mathrm{NZ}$ & $\mathrm{NZ}$ \\
\hline Average score & 4.26 & 4.44 & 4.17 & $\mathrm{NZ}$ & $\mathrm{NZ}$ & $\mathrm{NZ}$ \\
\hline
\end{tabular}

In regard to chemical composition of meat, no statistically significant differences were established $(\mathrm{P}>0.05)$. Meat tenderness was significantly better in groups which consumed the preparation ,Tradi-Lin“and it was $11.60 ; 9.90$ and $9.74 \mathrm{~kg}(\mathrm{P}<0.05)$. Cooking loss and roasting loss showed no differences between studied treatments $(\mathrm{P}>0.05)$. Data presented in table shows that adding of the preparation „Tradi-Lin“ to diets for fattening cattle had significant effect on obtaining of meat of lighter colour $(\mathrm{P}<0.05)$ expressed through total pigments $\left(139.18 ; 136.00\right.$ and $130.02 \mathrm{mg} / \mathrm{kg}$, in the order of treatments $\mathrm{C}, \mathrm{T}_{1} \mathrm{I} \mathrm{T}_{2}$ ) and which were in correlation with colour of meat expressed as lightness (Light) (34.13; 36.13 and 38.26) in the same order of treatments $(\mathrm{P}<0.05)$ measured on apparatus Minolta Chroma Meter CR-400 (Minolta Co., Ltd., Osaka, Japan). Lighter meat colour is more desirable from the aspect of consumers. Average sensory score included smell/odour, aroma, tenderness and succulence, and scores for individual properties were from 1 to 5 , higher score marked better or more desirable property, and no difference between treatments was recorded: $4.07 ; 4.13$ and $4.24(\mathrm{P}>0.05)$. However, regardless of the absence of statistical difference in obtained results, it can be concluded that the general impression was that the sum of scores obtained in trial groups was better compared to control.

Results of the carcass side dissection are presented in Table 5. 
Table 5. Carcass side dissection

\begin{tabular}{|l|c|c|c|c|c|c|c|c|c|}
\hline \multirow{2}{*}{\begin{tabular}{l|c|c|c|c|c|c|c|} 
Parameter \\
\cline { 2 - 10 }
\end{tabular}} & $\mathrm{kg}$ & $\%$ & $\mathrm{~kg}$ & $\%$ & $\mathrm{~kg}$ & $\%$ & $\begin{array}{c}\text { Control } \\
\text { vs. } \mathrm{T}_{1}\end{array}$ & $\begin{array}{c}\mathrm{C}_{1} \\
\text { Von. }_{2}\end{array}$ & $\begin{array}{c}\mathrm{T}_{1} \\
\text { vs. }_{2}\end{array}$ \\
\hline $\begin{array}{l}\text { Mass of left carcass } \\
\text { side }\end{array}$ & 153.85 & & 159.65 & & 161.55 & & $\mathrm{NZ}$ & $\mathrm{NZ}$ & $\mathrm{NZ}$ \\
\hline Muscle tissue & 108.20 & 70.29 & 112.76 & 70.64 & 113.37 & 70.25 & $\mathrm{NZ}$ & $\mathrm{NZ}$ & $\mathrm{NZ}$ \\
\hline Fat tissue (tallow) & 18.28 & 11.93 & 19.86 & 12.42 & 20.72 & 12.74 & $\mathrm{NZ}$ & $\mathrm{NZ}$ & $\mathrm{NZ}$ \\
\hline Connective tissue & 0.91 & 0.59 & 1.03 & 0.64 & 1.01 & 0.62 & $\mathrm{NZ}$ & $\mathrm{NZ}$ & $\mathrm{NZ}$ \\
\hline Bones & 26.29 & 17.07 & 25.86 & 16.20 & 26.28 & 16.27 & $\mathrm{NZ}$ & $\mathrm{NZ}$ & $\mathrm{NZ}$ \\
\hline
\end{tabular}

Data presented in Table 5 shows that mass of beef carcass sides showed no difference, and also there were no differences in the amount of muscle, fat, connective tissue or mass of bones $(\mathrm{P}>0.05)$. Results of our research are in concordance with results obtained by Bartle et al. (1994) and Felton and Kerley (2004) who pointed out that including lipid sources in finishing diets has generally not affected carcass composition.

As a result of carried out research and based on presented results it can be concluded that adding of $0.7 \mathrm{~kg}$ compared to $0.3 \mathrm{~kg}$ gives more pronounced results in regard to content of PUFA as well as total pigments, considering that light colour of meat is more desired from the aspect of consumers.

It can be said that production of meat of improved quality will be accepted primarily by producers with closed production cycle, i.e. producers with their own slaughterhouse, so that production of meat of certain quality can be organized, without disturbing the regular commercial production process.

Also, economical analysis of the production of beef of improved quality was done: - cost of $1 \mathrm{~kg}$ of „Tradi-Lin" is 1.2 Euros which means that inclusion of $0.7 \mathrm{~kg}$ of this preparation in diets during the last two months of fattening would increase the price of meat by 0.155 Euros per $\mathrm{kg}$ of carcass side, which is minor increase in price compared to realized effects.

\section{Conclusion}

By including the preparation "Tradi-Lin", which consists of heat treated flax seed as source of omega -3 fatty acids into diets for fattening cattle, it is possible to obtain meat with properties of functional food, i.e. enriched by this essential substances with simultaneous decrease of the omega-6:omega-3 ratio and reduction of the content of trans poly unsaturated fatty acids. Adding of $0.7 \mathrm{~kg}$ of this preparation to diets during the last two months of fattening was economically justified because it leads to minor increase in price ( 0.155 Euros per $\mathrm{kg}$ of carcass side) compared to the effects which are achieved. From the nutritional point of 
view, or health aspect, results obtained in this research are very important because omega -3 fatty acids are of essential importance for preservation of health.

\title{
Acknowledgment
}

Research was financed by the Ministry of Education and Science, Republic of Serbia, project TR 31053.

\section{Proizvodnja junećeg mesa sa svojstvima funkcionalne hrane}

\author{
Lj. Sretenović, V.Pantelić, M. Novaković, Ž. Novaković, D.Ostojić-Andrić
}

\section{Rezime}

U radu su predstavljeni efekti korišćenja proizvoda „Tradi-Lin“ kao izvora omega-3 masnih kiselina u obrocima junadi u tovu. Proizvod „TradiLin“dobijen je termičkom obradom semena lana, sadrži 58\% omega-3 i 15\% omega-6 masnih kiselina od ukupno polinezasićenih masnih kiselina (PUFA) i predstavlja patent francuske firme Vitalac. Ogled je izveden na tri grupe simentalske rase junadi $(\mathrm{C}$, $\mathrm{T}_{1}$ i $\mathrm{T}_{2}$ ) sa po 15 grla u svakoj, u periodu dva meseca pred klanje. Obroci za sve grupe junadi bili su potpuno identični i bazirani na silaži cele biljke kukuruza i smeši koncentrata. Jedina razlika bila je ta što su grla pored osnovnog obroka dobijala 0, 300 i 700 g ,Tradi-Lin“ - a dnevno, respektivno. Na kraju ogleda grla su zaklana i određeni su najvažniji parametri hemijskog sastava i kvaliteta mesa. Dobijeni rezultati ukazuju da u intramuskularnoj masti leđnog dela $M$. longissimus dorsi (MLD) nije postojala razlika u sadržaju zasićenih $(50,89 ; 50,21 ; 50,32 \%)$ i nezasićenih $(49,15 ; 49,79 ; 49,66 \%)$ masnih kiselina među ispitivanim tretmanima $\left(\mathrm{C}, \mathrm{T}_{1}\right.$ i $\left.\mathrm{T}_{2}\right)$. Međutim, dodavanje ,TradiLin“- a uticalo je na promenu strukture intramuskularne masti u korist povećanja PUFA od 4,95 (C), na 5,98 $\left(\mathrm{T}_{1}\right)$ odnosno $7,31 \% \quad\left(\mathrm{~T}_{2}\right) \quad(\mathrm{P}<0.05)$. Treba posebno istaći povećanje sadržaja omega-3 masnih kiselina sa 0,36 (C) na 0,60 $\left(\mathrm{T}_{1}\right)$ odnosno na $0,76 \%\left(\mathrm{~T}_{2}\right),(\mathrm{P}<0,05)$. Jednovremeno povećao se sadržaj omega-6 masnih kiselina od 4,51 (C) na 4,94 ( $\left.\mathrm{T}_{1}\right)$ odnosno $6,22 \%\left(\mathrm{~T}_{2}\right)(\mathrm{P}>0,05)$ a odnos omega -6/omega-3 smanjen sa 12,25 (C) na 8,22 $\left(\mathrm{T}_{1}\right)$ $(\mathrm{P}<0,05)$ i 8,62 $\left(\mathrm{T}_{2}\right)$, ( $\left.\mathrm{P}<0,01\right)$. Sadržaj trans nezasićenih masnih kiselina koje su nepoželjne smanjen je sa $3,37 \%(\mathrm{C})$ na $2,43 \%\left(\mathrm{~T}_{1}\right)(\mathrm{P}<0,05)$ odnosno $2,36 \%\left(\mathrm{~T}_{2}\right)$. Dodavanje $0,7 \mathrm{~kg}$ ovog preparata u obroke u zadnjih dva meseca tova potpuno je ekonomski opravdano jer utiče na zanemarljivo povećanje cene u odnosu efekte koji se dobijaju. Sa nutricionističkog aspekta ovi rezultati imaju veliki značaj imajući u vidu da omega-3 masne kiseline imaju vitalnu ulogu u očuvanju zdravlja ljudi. 


\section{References}

AMSA (1995): Research guidelines for cookery, sensory evaluation, and instrumental tenderness measurements of fresh meat. Am. Meat Sci. Assoc., Savoy, IL.

AOAC (1990): Official methods of analysis. Washington, DC: Association of Official Analytical Chemists.

BARTLE S., PRESTON J., MILLER M. (1994): Dietary energy source and density: effects of roughage source, roughage equivalent, tallow level, and steer type on feedlot performance and carcass characteristics. J. Anim. Sci., 72, 19431953.

CONNOR E. (2000): Importance of n-3 fatty acids in health and disease. Am. J. Clin. Nutr., 71, 171-175.

DROUILLARD S., FARRAN T., BLASI D., LABRUNE H., MONTGOMERY S., SINDT J., COETZER C., HUNTER R., SPIRE M., ELSASSER T., HIGGENS J. (2000): Modulation of immune response in feeder cattle with flaxseed. Proc. 58th Flax Institute, March 23-25, Fargo, N.D., 53-62.

DROUILLARD S., GOOD E., GORDON C., KESSEN J., SULPIZIO, MONTGOMERY S., SINDT J. (2002): Flaxseed and flaxseed products for cattle: Effects on health, growth performance, carcass quality and sensory attributes. Proc. 59th Flax Institute, March 21-23, Fargo, N.D., 72-87.

DROUILLARD S., SEYFERT M., GOOD E., LOE E., DEPENBUSCH B., DAUBERT R. (2004): Flaxseed for finishing beef cattle: Effects on animal performance, carcass quality and meat composition. Proc. 60th Flax Institute, March 17-19, Fargo, N.D., 108-117.

FELTON E., KERLEY M. (2004): Performance and carcass quality of steers fed different sources of dietary fat. J. Anim. Sci., 82, 1794-1805.

HARRIS K., HAGGERTY W. (1993): Assays for potentially anti-carcinogenic phytochemicals in flaxseed. Cereal Foods World, 38, 147-151.

IRIBARREN C, MARKOVITZ H., JACOBS R, SCHREINER J, DAVIGLUS M., HIBBELN R. (2004) : Dietary intake of $n-3$ fatty acids: Relation with hostility in young adults: the CARDIA study. Eur.J Clin Nutr., 58, 1, 24-31.

LAURIN D., VERREAULT R., LINDSAY J., DEWAILLY E., HOLUB J. (2003): Omega 3 Fatty acids and risks of cognitive impairment and dementia. J. Alzheimers Dis., 5, 4, 315-22

LEGRAND P., BOURRE J.M., DESCOMPS B., DURAND G., RENAUD S. (2001): Lipides. In: Apports nutritionnels conseillés pour la population française, 3ème édition. 63-82.

MADDOCK D., ANDERSON V., BERG P., MADDOCK R., MARCHELLO M. (2003): Influence of level of flaxseed addition and time fed flaxseed on carcass 
characteristics, sensory panel evaluation and fatty acid content of fresh beef. Proc. 56th Reciprocal Meats Conference, Am. Meat Sci. Assoc., Columbia, Mo.

MADDOCK D., BAUER M., KOCH K., ANDERSON V., MADDOCK R., BARCELO-COBLIJN G., MURPHY E., LARDY P. (2006): The effect of processing flax in beef feedlot rations on performance, carcass characteristics and trained sensory panel ratings. J. Anim.Sci., 84, 1544-1551.

NATIONAL RESEARCH COUNCIL (NRC) (2001): Nutrient requirements of dairy cattle. Seventh revised edition, National Academy Press, Washington, DC.

SRETENOVIĆ LJ., ALEKSIĆ S., PETROVIĆ M.M., PETROVIĆ M.P., STOJANOVIĆ LJ. (2007): Application of modern technology of nutrition in high yielding cows in dry period and early lactation. Biotechnology in Animal Husbandry, 23, 1-2, 30-40.

SRETENOVIĆ LJ, ALEKSIĆ S., PETROVIĆ M.M., PANTELIĆ V., BESKOROVAJNI R., RUŽIĆ D., ĐEDOVIĆ R. (2009): Dobijanje mesa i mleka sa osobinama funkcionalne hrane. Zbornik naučnih radnika, institut "PKB Agroekonomik", 67-78.

SRETENOVIĆ LJ., PANTELIĆ V., NOVAKOVIĆ Ž. (2009a): Importance of utilization of omega-3 fatty acids in human and animal nutrition. Biotechnology in Animal Husbandry, 25, 5-6, 439-449.

STATISTICA V.6. STATSOFT, INC. (2003).

THOMPSON U., CHEN J., HUI E., MANN J. (2004): Interactive effects of flaxseed and tamoxifen on human breast cancer. Proc. 60th Flax Institute, March 17-19, Fargo, N.D., 86-90. 